\title{
RENAL INVOLVEMENT IN LEPTOSPIROSIS
}

\author{
Galya Gancheva \\ Department of Infectious Diseases, Epidemiology, Parasitology and Tropical \\ Medicine \\ Medical University - Pleven, Bulgaria
}

\section{SUMMARY:}

Renal involvement is a common feature of leptospirosis. It is variable from mild to severe acute renal failure. Materials and methods: We performed analysis of 100 consecutive leptospirosis cases treated in Clinic of Infectious Diseases at University Hospital - Pleven (1976-2012) (90 male, age $37 \pm 18$ years, lethal outcome in $13 \%$ ), followed by comparative analysis of group with renal involvement $\left(\mathrm{n}_{1}=59\right)$ versus group without renal involvement (controls: $\mathrm{n}_{2}=41$ ). Results: Fever (100\%), hepatomegaly (92\%), myalgia (86\%), nausea and vomiting (84\%), splenomegaly (74\%), oliguria $(69 \%)$, headache $(67 \%)$, jaundice $(63 \%)$, hypotension $(49 \%)$, abdominal pain (41\%), and hemorrhagic diathesis (37\%) were the characteristic manifestations and had had a significantly higher prevalence in the group with renal involvement. Blood urea nitrogen (mean $27.9 \pm 16.9 \mathrm{mmol} / \mathrm{L}$ ) and serum creatinine (mean 349.9 $\pm 190.1 \mu \mathrm{mol} / \mathrm{L}$ ) were the main laboratory parameters that expressed renal dysfunction in this group. Dialysis was performed in twelve severe cases. Conclusion: Leptospirosis with acute renal failure is a severe disease and requires early diagnosis and prompt treatment.

Key words: acute renal failure; hepatic dysfunction; leptospirosis; renal involvement

\section{INTRODUCTION:}

Leptospirosis, the most widespread zoonosis, presenting in humans with protean manifestations, is usually encountered in warm-climate and developing regions ${ }^{1,2}$ but is also reported in European countries ${ }^{3}$. Renal involvement is a common feature of both mild and severe forms of this reemerging but frequently ignored infectious disease $\mathrm{e}^{4,5}$. Subclinical infection, and even the anicteric febrile disease, are self-limiting forms and thus carry an excellent prognosis ${ }^{6}$. However, up to $10 \%$ of leptospirosis infections may induce acute renal failure (ARF) and are associated with significant morbidity and mortality ${ }^{7}$. Unfortunately, leptospirosis is rarely considered as a possible cause of ARF. The clinical and laboratory features of leptospirosis cases presenting as ARF, and their outcome are described in few large series $1,3,8,9$.

Leptospirosis is less common in Bulgaria. A database and official registration of leptospirosis was initiated in 1953. A mean annual incidence rate of 0.9 to 3.1 per 100000 was reported during the period 1953-1968 followed by decreasing to 0.1 per 100000 population during the next ten years. Since 1976 mean annual incidence of 0.37 per 100000 was reported ${ }^{10}$. We were aimed to characterize in details all consecutive cases due to leptospirosis infection, treated in the University Hospital - Clinic of Infectious Diseases, Pleven, during a 36-year period (1976-2012).

\section{MATERIALS AND METHODS:}

A retrospective database for patients presenting with leptospirosis (1976-1984) was initiated and continued prospectively to the March 31st 2012. Subjects were screened by microscopic agglutination test (MAT) for leptospirosis (in the National Reference Laboratory at National Center of Infectious and Parasitic Diseases - Sofia). A positive diagnosis was confirmed if an initial titre of $\geq 100$ for MAT was observed. The following items were included in the database, for each patient: demographic data, clinical symptoms and laboratory parameters on admission, and outcome.

The patients were grouped in group with renal involvement (serum creatinine level $>135 \mu \mathrm{mol} / \mathrm{L}$ ) and control group (serum creatinine level $<135 \mu \mathrm{mol} / \mathrm{L}$ ) after analysis of data for whole series. Comparative analysis was performed group with renal involvement $\left(\mathrm{n}_{1}=59\right)$ versus control group $\left(\mathrm{n}_{2}=41\right)$. The data were analysed using the Statgraphics Plus Version 2.1. package. We used the t-test and for nonparametric distributions, the $\chi^{2}$ test; $p<0.05$ was considered to be significant.

\section{RESULTS:}

One hundred patients - age $37 \pm 18(8-78)$ years, 90 males, urban residents $61 \%$, with leptospirosis were treated in Clinic of Infectious Diseases at University Hospital Pleven, Bulgaria since January 1st 1976 to March 31st 2012. The mean annual incidence of leptospirosis for 36-year period in Pleven' region was 0.37 per 100000 population. It correlated with those for the country but significantly differed in some of years (Figure 1). An clinical diagnosis of leptospirosis was established before referral to our clinic in $60 \%$ of the cases, although exposure to animal excrements after water and animal contacts (57\% and $34 \%$, respectively) was certified in $88 \%$ of the cases. Summer predominance (78 cases) was observed - number of cases during June, July, August and September 
was $12,25,29$ and 12 , respectively.

The clinical signs and symptoms on admission in the Clinic of Infectious Diseases are shown on Table 1. The clinical manifestations for the whole series ( $>50 \%$ prevalence) were fever $(100 \%)$, hepatomegaly $(92 \%)$, myalgia $(86 \%)$, nausea and vomiting $(84 \%)$, splenomegaly $(74 \%)$, oliguria $(69 \%)$, headache $(67 \%)$, jaundice $(63 \%)$. Oligo/anuria, jaundice, conjunctival suffusions, hepatomegaly and splenomegaly, abdominal pain, hemorrhagic diathesis had significantly higher prevalence in the group with renal involvement. Hypotension, myocarditis, acute respiratory failure and pancreatitis had observed only in the group with renal involvement. Aseptical meningitis with polymorphonuclear pleocytosis in cerebrospinal fluid was observed in groups with and without renal involvement (11 and 10 cases, respectively; $p>0.05$ ).

Laboratory investigations revealed that blood urea nitrogen, serum creatinine, serum bilirubin, and serum amylase levels were significantly higher in the group with renal involvement. Total proteins and albumins were decreased in the same group due to ARF and hepatic dysfunction (Table 2).

Oliguria with low density (95\%), albuminuria (78\%) and hematuria (58\%) were evidences for renal dysfunction. Hypokalemia and hyponatremia were encountered in $38 \%$ and $12 \%$, respectively. Blood nitrogen parameters were elevated (blood urea mean $27.9 \pm 16.9 \mathrm{mmol} / \mathrm{L}$ and serum creatinine mean $349.9 \pm 190.1 \mu \mathrm{mol} / \mathrm{L}$ ). Dialysis was performed in twelve severe cases.

There were thirteen deaths - all in the group with renal involvement. All patients with unfavorable outcome had, besides ARF, at least two other major organ failures. Affected consciousness and multi-site bleeding were seen in all deceased patients.

\section{DISCUSSION:}

Although the most widespread zoonosis, and a frequent disease in warm, humid climate countries, leptospirosis is a rare condition in economically developed regions, accounting for $<1.2$ new cases/100 000 population/ year in United States and Western Europe ${ }^{8}$. Leptospirosis is usually spread to man, the final host, from animal reservoirs (especially rats) and depends upon chronic renal infection and shedding of virulent Leptospira interrogans in infected animals' urine. Infection by L.interrogans can cause renal tubular and microvascular injury, interstitial nephritis and ultimately, in $10 \%$ of cases, $\mathrm{ARF}^{4}$.

We report a large series of cases due to leptospirosis. The annual incidence of leptospirosis ARF in the region of Pleven (central-northtern part of Bulgaria) is 0.37/100 000 (mean $11.6 \mathrm{cases} / \mathrm{year}$ ). This incidence is explained in part by the presence of four rivers in this region of the country Danube, Iskar, Vit and Osam. The common features were fever, hepatomegaly, conjunctival suffusions, myalgia (pathognomonic in calf muscles), nausea and vomiting, splenomegaly, oligoanuria, headache, jaundice, leukocytosis, thrombocytopenia, elevated blood nitrogen parameters and slightly elevated transaminases. Compared to the other series featuring ARF in leptospirosis ${ }^{3}$, there were significant differences in the prevalence of haemorrhagic diathesis, which we found to be more than two times less frequent, but compared with series studied by Yang CW et al. (2001) it is compatible with our patients ${ }^{7}$.

Hypotension was encountered in approximately half of cases. Dehydration (previously reported as an aetiological factor of ARF) may have a role ${ }^{5}$. We consider myocarditis as probable cause, a hypothesis supported by the evidence of numerous ECG abnormalities recorded in patients with circulatory failure.

We found a lower prevalence of gastrointestinal symptoms such as abdominal pain (41\%), diarrhoea (15\%), although digestive involvement is reported by other retrospective series ${ }^{1,3}$.

Aseptic meningitis (in $21 \%$ of our cases) indicates the importance of neurological involvement in leptospirosis, secondary to direct meningeal infection or possibly more frequently to the host immune response ${ }^{4}$. There was no different prevalence of meningitis in two groups of patients in our study ( $p>0.05)$.

We consider that when ARF is presented, leptospirosis is a serious infection with severe multi-systemic organ involvement and ultimately failure. There are several ways in which the kidney is injured in leptospirosis: a classical immuno-allergic reaction to leptospira endotoxins ${ }^{11}$, direct inhibition of $\mathrm{Na} / \mathrm{K} / \mathrm{ATPase}$ in renal epithelial cells and cells from renal medulla ${ }^{12}$ or, as Yang C. et al (2001) demonstrated, induction of pro-inflammatory pathways in the medullary thick ascending limb cells ${ }^{7}$. The addition of outer membrane protein extract from L.shermani to cultured medullary thick ascending limb cells induces a significant nuclear DNA binding of the NF- $\kappa-\mathrm{B}$ transcription factor. In line with these findings, pathological data obtained from deceased patients and reported by Covic A. et al. (2003) showed important tubulo-interstitial lesions. There was a high prevalence of tubular dysfunctions in that report: $\mathrm{K}^{+}$- and $\mathrm{Na}^{+}$-wasting defects, incomplete tubular type II acidosis ${ }^{3}$. Hypokalaemia was found in our series with a prevalence of $38 \%$, similar to found by Covic et al. $(37 \%)^{3}$. Therefore these defects should be actively and routinely investigated in all leptospira cases, as well as particular attention being given to hypokalaemia and hyponatraemia in the management of these patients. Other causes of tubular dysfunction are only indirectly related to leptospira infection: hypotension (in half of our patients), endotoxin-induced vasoconstriction and renal ischaemia secondary to the circulatory failure 5 .

Survival was comparable in our population with other leptospiral ARF series ${ }^{1,7}$, supporting a major role of severity of renal dysfunction. Liver dysfunction was reversible in all 
patients. Deceased patients had severe multi-organ failure syndrome, with respiratory and circulatory failure, multi-site bleeding and meningo-cerebral involvement. Five of deceased patients had a severe pancreatic involvement.

In conclusion: Leptospirosis with ARF is a severe disease, frequently leading to multi-organ failure, and death. The prompt dialysis and adequate treatment improve prognosis.

Figure 1. Mean annual incidence of leptospirosis in Bulgaria and Pleven region (1976-2011).

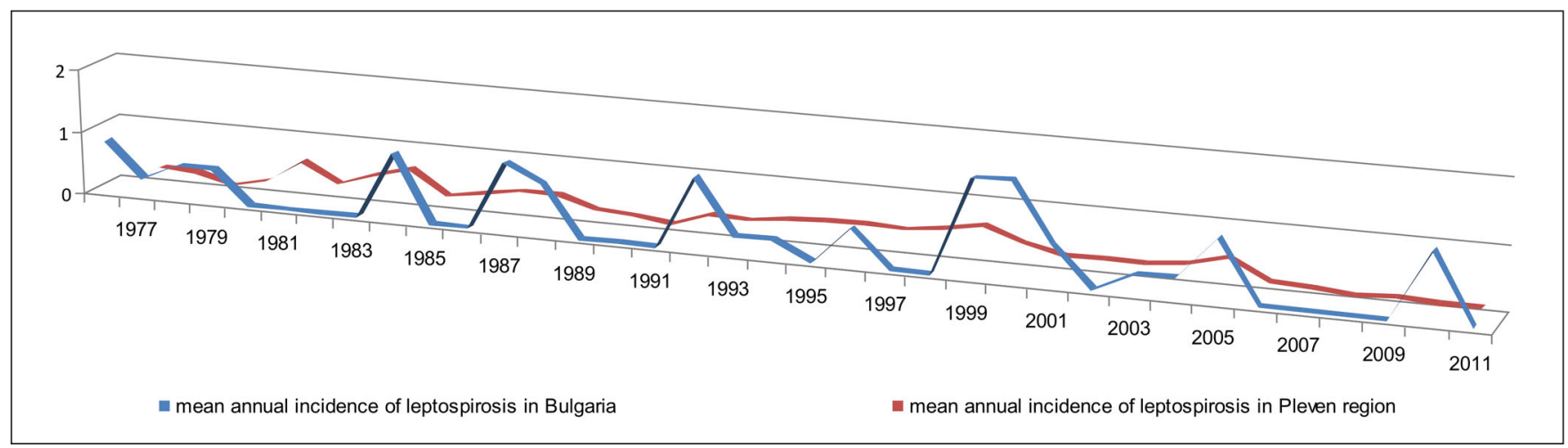

Table 1. Leptospirosis in Pleven region (1976-2012) - prevalence of symptoms in whole series and compared in group with renal involvement versus control group (without renal involvement).

\begin{tabular}{|l|c|c|c|c|}
\hline Symptoms & $\begin{array}{c}\text { Whole series } \\
(\mathrm{n}=100)\end{array}$ & $\begin{array}{c}\text { Group with renal } \\
\text { involvement }\left(\mathrm{n}_{1}=59\right)\end{array}$ & $\begin{array}{c}\text { Control group }- \\
\text { without renal } \\
\text { involvement }\left(\mathrm{n}_{2}=41\right) \\
\%\end{array}$ & $\mathrm{p}$ \\
\hline Fever & 100 & 100 & 100 & $=0$ \\
Hepatomegaly & 92 & 100 & 80 & $<0.005$ \\
Conjunctival suffusions & 87 & 97 & 73 & $<0.0005$ \\
Myalgia & 86 & 88 & 83 & $>0.05$ \\
Nausea and vomiting & 84 & 81 & 88 & $>0.05$ \\
Splenomegaly & 74 & 92 & 49 & $<0.0005$ \\
Oligo/anuria & 69 & 95 & 32 & $<0.0005$ \\
Headache & 67 & 56 & 83 & $<0.01$ \\
Jaundice & 63 & 80 & 39 & $<0.01$ \\
Tachycardia & 54 & 69 & 32 & - \\
Hypotension & 49 & 64 & 0 & $<0.025$ \\
Abdominal pain & 41 & 58 & 17 & $<0.01$ \\
Hemorrhagic diathesis & 37 & 35 & 2 & - \\
Myocarditis & 21 & 36 & 0 & $>0.05$ \\
Meningitis & 21 & 19 & 24 & $>0.05$ \\
Diarrhea & 15 & 22 & 5 & - \\
Acute respiratory failure & 14 & 24 & 0 & - \\
Pancreatitis & 7 & 12 & 0 & \\
\hline
\end{tabular}


Table 2. Leptospirosis in Pleven region (1976-2012) - laboratory findings in whole series and compared in group with renal involvement versus control group (without renal involvement).

\begin{tabular}{|c|c|c|c|c|c|}
\hline Parameter & $\begin{array}{l}\text { Reference } \\
\text { value }\end{array}$ & $\begin{array}{c}\text { Whole series - } \\
\text { mean } \pm \mathrm{SD} \\
(\text { min-max })\end{array}$ & $\begin{array}{l}\text { Group with renal } \\
\text { involvement - } \\
\text { mean } \pm \mathrm{SD} \\
\text { (min-max) }\end{array}$ & $\begin{array}{c}\text { Control group - } \\
\text { mean } \pm \text { SD } \\
\text { (min-max) }\end{array}$ & $\mathrm{p}$ \\
\hline $\begin{array}{l}\text { Hemoglobin } \\
(\mathrm{g} / \mathrm{L})\end{array}$ & $120-188$ & $\begin{array}{l}132 \pm 20 \\
(65-168)\end{array}$ & $\begin{array}{l}132 \pm 21 \\
(65-168)\end{array}$ & $\begin{array}{c}132 \pm 17 \\
(101-157)\end{array}$ & $>0.05$ \\
\hline $\begin{array}{l}\text { Leucocytes } \\
\text { (cells } \times 10^{9} / \mathrm{L} \text { ) }\end{array}$ & $4.0-11.0$ & $\begin{array}{c}13.5 \pm 6.5 \\
(2.9-32)\end{array}$ & $\begin{array}{l}15.2 \pm 6.4 \\
(5.2-27.6)\end{array}$ & $\begin{array}{c}11.0 \pm 5.9 \\
(2.9-32)\end{array}$ & $<0.001$ \\
\hline $\begin{array}{l}\text { Neutrophils } \\
(\%)\end{array}$ & $50-80$ & $\begin{array}{l}81 \pm 16 \\
(60-96)\end{array}$ & $\begin{array}{l}89 \pm 18 \\
(90-96)\end{array}$ & $\begin{array}{l}60 \pm 11 \\
(60-82)\end{array}$ & $<0.025$ \\
\hline $\begin{array}{l}\text { Platelets } \\
\text { (cells x 109/L) }\end{array}$ & $150-400$ & $\begin{array}{c}146 \pm 104 \\
(8-445)\end{array}$ & $\begin{array}{c}128 \pm 100 \\
(8-445)\end{array}$ & $\begin{array}{l}192 \pm 102 \\
(35-408)\end{array}$ & $<0.025$ \\
\hline $\begin{array}{l}\text { Urea } \\
(\mathrm{mmol} / \mathrm{L})\end{array}$ & $1.7-8.3$ & $\begin{array}{c}22.5 \pm 16.9 \\
(2.8-98.6)\end{array}$ & $\begin{array}{c}27.9 \pm 16.9 \\
(5.2-98.6)\end{array}$ & $\begin{array}{l}8.6 \pm 3.8 \\
(2.8-19)\end{array}$ & $<0.0005$ \\
\hline $\begin{array}{l}\text { Creatinine } \\
(\mu \mathrm{mol} / \mathrm{L})\end{array}$ & $44.2-134$ & $\begin{array}{c}279.7 \pm 197 \\
(56-818)\end{array}$ & $\begin{array}{c}349.9 \pm 190.1 \\
(136-818)\end{array}$ & $\begin{array}{l}101 \pm 19 \\
(56-130)\end{array}$ & $<0.0005$ \\
\hline $\begin{array}{l}\mathrm{K}^{+} \\
(\mathrm{mmol} / \mathrm{L})\end{array}$ & $3.5-5.6$ & $\begin{array}{l}4.1 \pm 0.7 \\
(2.6-6.5)\end{array}$ & $\begin{array}{l}4.0 \pm 0.8 \\
(2.6-6.5)\end{array}$ & $\begin{array}{l}4.2 \pm 0.7 \\
(2.9-5.7)\end{array}$ & $>0.05$ \\
\hline $\begin{array}{l}\mathrm{Na}^{+} \\
(\mathrm{mmol} / \mathrm{L})\end{array}$ & $130-151$ & $\begin{array}{l}138 \pm 7.1 \\
(112-155)\end{array}$ & $\begin{array}{l}136 \pm 7.1 \\
(112-150)\end{array}$ & $\begin{array}{l}140 \pm 6.3 \\
(126-155)\end{array}$ & $<0.01$ \\
\hline $\begin{array}{l}\text { Total bilirubin } \\
(\mu \mathrm{mol} / \mathrm{L})\end{array}$ & $3.4-21$ & $\begin{array}{c}157.8 \pm 71.5 \\
(5.1-801)\end{array}$ & $\begin{array}{c}205.2 \pm 191 \\
(13.1-801)\end{array}$ & $\begin{array}{l}77.8 \pm 57.9 \\
(5.1-368.5)\end{array}$ & $<0.0005$ \\
\hline $\begin{array}{l}\text { Direct bilirubin } \\
(\mu \mathrm{mol} / \mathrm{L})\end{array}$ & $0.8-8.5$ & $\begin{array}{c}139 \pm 31.7 \\
(2.5-564)\end{array}$ & $\begin{array}{c}176.6 \pm 140.9 \\
(5.8-564)\end{array}$ & $\begin{array}{l}70.4 \pm 66.1 \\
(2.5-289.8)\end{array}$ & $<0.0005$ \\
\hline $\begin{array}{l}\text { ASAT } \\
(\mathrm{IU} / \mathrm{L})\end{array}$ & $\mathrm{J} 37$ & $\begin{array}{c}112 \pm 18.5 \\
(6-625)\end{array}$ & $\begin{array}{c}141 \pm 136 \\
(27-625)\end{array}$ & $\begin{array}{l}68 \pm 65 \\
(6-320)\end{array}$ & $<0.001$ \\
\hline $\begin{array}{l}\text { ALAT } \\
(\mathrm{IU} / \mathrm{L})\end{array}$ & $\mathrm{J} 40$ & $\begin{array}{c}96 \pm 77.9 \\
(11-382)\end{array}$ & $\begin{array}{l}107 \pm 84 \\
(11-382)\end{array}$ & $\begin{array}{c}78 \pm 64 \\
(12-264)\end{array}$ & $<0.05$ \\
\hline $\begin{array}{l}\text { GGT } \\
(\mathrm{IU} / \mathrm{L})\end{array}$ & $15-28$ & $\begin{array}{c}168 \pm 57.7 \\
(16-568)\end{array}$ & $\begin{array}{c}174 \pm 152 \\
(31-556)\end{array}$ & $\begin{array}{c}148 \pm 129 \\
(16-568)\end{array}$ & $>0.05$ \\
\hline $\begin{array}{l}\text { Alkaline phosphatase } \\
\text { (IU/L) }\end{array}$ & $50-260$ & $\begin{array}{l}313 \pm 237 \\
(37-1431)\end{array}$ & $\begin{array}{l}303 \pm 232 \\
(37-1431)\end{array}$ & $\begin{array}{l}333 \pm 250 \\
(90-1099)\end{array}$ & $>0.05$ \\
\hline $\begin{array}{l}\text { Lactatedehydrogenase } \\
\text { (IU/L) }\end{array}$ & $100-360$ & $\begin{array}{l}980 \pm 550 \\
(287-2305)\end{array}$ & $\begin{array}{l}970 \pm 565 \\
(287-2305)\end{array}$ & $\begin{array}{l}1054 \pm 590 \\
(637-1472)\end{array}$ & $>0.05$ \\
\hline $\begin{array}{l}\text { Creatine kinase } \\
(\mathrm{IU} / \mathrm{L})\end{array}$ & $80-190$ & $\begin{array}{c}2508 \pm 1948 \\
(68-10438)\end{array}$ & $\begin{array}{c}2891 \pm 2822 \\
(78-10438)\end{array}$ & $\begin{array}{c}212 \pm 203 \\
(68-355)\end{array}$ & $<0.025$ \\
\hline $\begin{array}{l}\text { Total protein } \\
(\mathrm{g} / \mathrm{L})\end{array}$ & $58-80$ & $\begin{array}{l}64.5 \pm 9.2 \\
(47.8-87)\end{array}$ & $\begin{array}{l}62.1 \pm 9.4 \\
(47.8-87) \\
\end{array}$ & $\begin{array}{l}69.8 \pm 6.1 \\
(59-80.5) \\
\end{array}$ & $<0.0005$ \\
\hline $\begin{array}{l}\text { Albumins } \\
(\mathrm{g} / \mathrm{L})\end{array}$ & $35-55$ & $\begin{array}{c}36.2 \pm 7.8 \\
(18.5-51)\end{array}$ & $\begin{array}{l}34.1 \pm 7.1 \\
(18.5-46)\end{array}$ & $\begin{array}{l}43.6 \pm 5.6 \\
(33.5-51)\end{array}$ & $<0.0005$ \\
\hline $\begin{array}{l}\text { Fibrinogen } \\
(\mathrm{g} / \mathrm{L})\end{array}$ & $2.0-4.5$ & $\begin{array}{c}6.76 \pm 2.39 \\
(1.4-12)\end{array}$ & $\begin{array}{c}7.17 \pm 2.34 \\
(2.2-12)\end{array}$ & $\begin{array}{c}5.84 \pm 2.28 \\
(1.4-10.8)\end{array}$ & $<0.01$ \\
\hline
\end{tabular}




\begin{tabular}{|l|c|c|c|c|c|}
\hline $\begin{array}{l}\text { Prothrombin index } \\
(\%)\end{array}$ & $80-110$ & $\begin{array}{c}86 \pm 18 \\
(64-114)\end{array}$ & $\begin{array}{c}86 \pm 17 \\
(41-114)\end{array}$ & $\begin{array}{c}88 \pm 21 \\
(64-108)\end{array}$ & $>0.05$ \\
\hline Serum amylase & \multirow{2}{*}{$30-300$} & $\begin{array}{l}450 \pm 409 \\
(38-2302)\end{array}$ & $\begin{array}{l}513 \pm 443 \\
(38-2302)\end{array}$ & $\begin{array}{c}174 \pm 135 \\
(44-470)\end{array}$ & $<0.0005$ \\
\hline
\end{tabular}

\section{REFERENCES:}

1. Ko AI, Galvao Reis M, Ribeiro Dourado CM, Johnson WD Jr, Riley LW. Urban epidemic of severe leptospirosis in Brazil. Salvador leptospirosis Study group. Lancet. 1999 Sep; 354(9181):820-825. [PubMed]

2. Daher E, Zanetta DM, Cavalcante MB, Abdulkader RC. Risk factors for death and changing patterns in leptospirosis acute renal failure. $\mathrm{Am} \mathrm{J}$ Trop Med Hyg. 1999 Oct;61(4):630-634. [PubMed]

3. Covic A, David J. A. Goldsmith DJA, Gusbeth-Tatomir P, Seica A, Covic M. A retrospective 5-year study in Moldova of acute renal failure due to leptospirosis: 58 cases and a review of the literature. Nephrol Dial Transplant. 2003 Jun;18(6):1128-1134. [PubMed] [CrossRef]

4. Levett PN. Leptospirosis. Clin Microbiol Rev. 2001 Apr;14(2):296-326. [PubMed] [CrossRef]
5. Sitprija V, Losuwanrak K, Kanjanabuch T. Leptospiral nephropathy. Semin Nephrol 2003 Jan;23(1): 42-48. [PubMed]

6. Ashford DA, Kaiser RM, Spiegel RA, Perkins BA, Weyant RS, Bragg SL, et al. Asymptomatic infection and risk factors for leptospirosis in Nicaragua. Am J Trop Med Hyg. 2000 Nov-Dec; 63(5-6):249-254. [PubMed]

7. Yang $\mathrm{CW}, \mathrm{Wu} \mathrm{MS}$, Pan MJ. Leptospirosis renal disease. Nephrol Dial Transplant. 2001; 16(Suppl 5):7377. [PubMed] [CrossRef]

8. Katz AR, Ansdell VE, Effler PV, Middleton CR, Sasaki DM. Assessment of the clinical presentation and treatment of 353 laboratory-confirmed leptospirosis in Hawaii, 1974-1998. Clin Infect Dis. 2001 Dec 1;33(11):1834 1841. [PubMed] [CrossRef]

9. Spichler AS, Vilaca PJ, Athanazio DA, Albuquerque JOM, Buzzar M,
Castro B, et al. Predictors of Lethality in Severe Leptospirosis in Urban Brazil. Am J Trop Med Hyg. 2008 Dec; 79(6): 911-914. [PubMed]

10. Gancheva G. Complex researches at leptospirosis. $P h D$ dissertation, MU - Pleven, Bulgaria, 2006. [in Bulgarian]

11. Vinh T, Faine S, Handley CJ, Adler B. Immunohistochemical studies of opsonic epitopes of the lipopolysaccharide of Leptospira interrogans serovar hardjo. FEMS Immunol Med Microbiol. 1994 Feb;8(2):99-103. [PubMed] [CrossRef]

12. Younes-Ibrahim M, Burth $P$, Faria MV, Buffin-Meyer B, Marsy S, Barlet-Bas C, et al. Inhibition of Na, KATPase by an endotoxin extracted from Leptospira interrogans: a possible mechanism for the physiopathology of leptospirosis. C R Acad Sci III. 1994 May;318(5):619-625. [PubMed]

\section{Address for correspondence:}

Assoc. Professor Galya Gancheva, MD, PhD,

Clinic of Infectious Diseases, University Hospital,

8a "Georgi Cochev" str., 5800 Pleven, Bulgaria; tel. +359 886416 ;

E-mail: galya_gancheva@abv.bg 